\title{
単発レーザー励起超音波の可視化
}

\author{
竹下 照雄 ${ }^{1-3}$, 沖原 伸一朗 1 , 㴰口 義浩 1,2 \\ 1光産業創成大学院大学光産業創成研究科 ( ₹431-1202 静岡県浜松市西区呉松町1955-1) \\ 2浜松ホトニクス (株)（テ430-8587 静岡県浜松市中区砂山町325-6 日本生命浜松駅前ビル） \\ 3(株) ジーワン・ラボ ( ₹431-1202 静岡県浜松市西区呉松町1955-1)
}

\section{Visualization of Propagating Ultrasonic Waves Induced by a Single Laser Pulse}

\author{
Teruo TAKESHITA, ${ }^{1-3}$ Shin-ichiro OKIHARA, ${ }^{1}$ and Yoshihiro TAKIGUCHI ${ }^{1,2}$ \\ ${ }^{1}$ The Graduate School for Creation of New Photonics Industry, 1955-1 Kurematsu, Nishi-ku, Hamamatsu, Shizuoka $431-1202$ \\ ${ }^{2}$ Hamamatsu Photonics K.K., 325-6 Sunayama, Naka-ku, Hamamatsu, Shizuoka 430-8587 \\ ${ }^{3}$ G1 Lab. Co., Ltd., 1955-1 Kurematsu, Nishi-ku, Hamamatsu, Shizuoka 431-1202
}

(Received November 20, 2007)

\begin{abstract}
We have been studying non-invasive and non-destructive methods for inspecting internal structures that use laser-induced ultrasonic waves and an optical measurement technique. As one solution, we propose a new method for determining the internal structure from images of propagating ultrasonic waves induced by a single laser pulse, using a visualization technique that uses a laser beam for illumination and an image-converter tube. In this paper, the captured images of propagating ultrasonic waves in the space-time domain with nanosecond time resolution and two-dimensional dynamic images with fifty nanosecond exposure time are presented and analyzed. This investigation demonstrates the suitability of this proposed method for industrial applications.
\end{abstract}

Key Words: Laser induced ultrasonic, Non destructive inspection, Single event measurement, Visualization, Framing streak camera

1.はじめに

半導体素子の生産過程においては，超音波探傷装置を 用いた素子の内部構造検査による品質管理が行われてい る. 現在行われている検査法は超音波振動子により超音 波の発生と検出を行うものが主流である。超音波振動子 を用いた検査法は，センサー部を検査試料に対しジェル や水などの液体を介して接触させた状態で2次元走査を行 うために液体除去工程が必要となり，更には品質管理工 数の増加やデー夕取得に時間が掛かるなどの問題点が指 摘されている。

これに替わる1つの方法として，パルスレーザーで超音 波を励起し，異なるレーザー光を用いて試料表面に現れ る表面弾性変位を検出する非接触・非破壊内部構造検査 法が研究1-4)されている. 報告されている検出法の多く は, 検査試料上にフォトダイオードなどの検出器を配置 し，これを2次元走査することで試料全体のデー夕を取得 する走査・積算方式であり，更にはこれにポンプアンド プローブ方式を組み合わせた時間分解計測手法4)もある。 近年では超音波探触子を試料に固定し，代わりにレー ザーを走査する半非接触方式5) も報告されているが，これ らの方法は1点1点のデータをコンピュータ上で画像に再
構成するために計測時間が掛かるという問題がある.

この様な状況の中で筆者らは，産業応用を目指し，ス ループットの高い非接触・非破壊内部構造検査法の開発 に着手した。 その第一フェーズとして, 内部構造推定の ための情報を得るために検査試料表面に単発パルスレー ザーを照射することで超音波を励起し，この超音波が試 料内部あるいは表面を伝播する動的挙動を励起パルス レーザーと波長の異なるCWレーザー光により可視化し， これをイメージコンバータ管を用いた超高速画像取得装 置で単一イベント撮影する手法6) (以後, 単発パルスレー ザー励起超音波画像化法)を開発したので報告する。この 手法は，1回の撮影で単発パルスにより励起された超音波 の時間に対する1次元空間挙動，あるいは2次元空間分布 の時間変化の取得が可能であるために計測時間を大幅に 短縮することができる。

本稿では, 提案した単発パルスレーザー励起超音波画 像化法の動作原理と装置構成を述べると共に，超音波探 傷を模したアクリルブロック内を伝播する超音波とアク リルブロック表面に蒸着した金属薄膜を伝わる超音波の 可視化・時間分解撮影例を示し，それらの超音波の伝搬 の解析について述べる. 


\section{2. 動作原理と装置構成}

単発パルスレーザー励起超音波画像化装置6) は, 動作原 理をFig. 1 (a)に示すようにパルスレーザーと, 検査試料 照明用CWレーザー，および試料表面を時間分解撮影する イメージコンバータ管7,8) とその接続光学系および駆動回 路により構成する。

本装置は，検査試料表面にパルスレーザーを照射する ことにより超音波を励起する。検査試料表面あるいは内 部を伝播する超音波は, 試料の圧力変化や微小な変位を 起こすため，これを検査試料照明用CWレーザー光によっ て可視化し時間分解撮影することで，超音波伝播を画像 化計測する。

試料の撮影には単一光子検出が可能な超高感度なイ メージコンバー夕管7,8)を用いる。ここでいうイメージコ ンバー夕管とは光電面, 偏向板, 蛍光面を備えた電子管 である。イメージコンバータ管の光電面に結像された試 料からの反射光像は外部光電効果により電子像に変換さ れ, 撮影現象と夕イミングに合わせて垂直・水平偏向板 に加えた偏向電圧によって時間情報が空間分布に置き換 えられた後にMCP (Micro-Channel Plate) ${ }^{9)}$ で2次元電子増倍 され，再び蛍光面で2次元蛍光像となり出力される10)。 イ メージコンバータ管は入射光像の切り出し方法により, 単発現象をFig. 1 (b) に示すように空間軸Xと時間軸 T，お よび光強度Iにより構成されるストリーク像11)，または同 図 (c) に示すように空間軸Xと空間軸 $\mathrm{Y}$ ，および光強度Iに より構成される連続した瞬間像を8枚並べたフレーミング 像7,8) として画像化することができる。フレーミング像に は，撮影の時系列の順番を番号で示した。蛍光面に出力

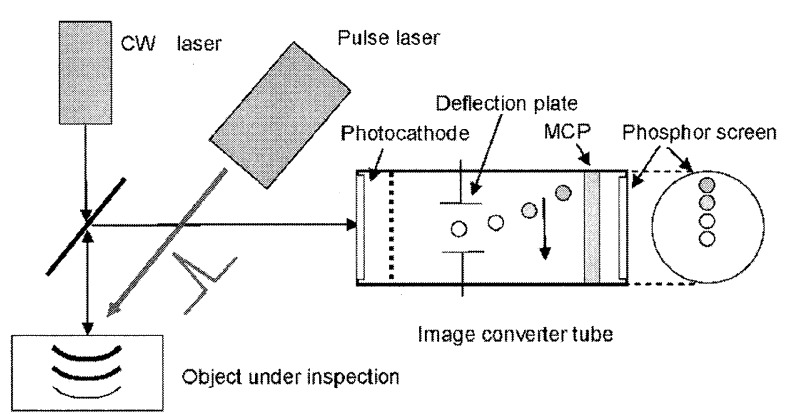

(a)

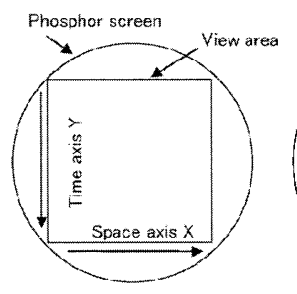

(b)

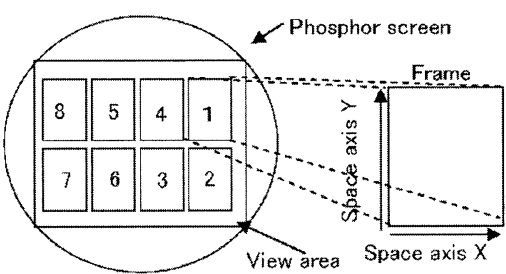

(c)
Fig. 1 (a) Operation principle of time-resolved imaging of this method, (b) streak image, and (c)framing images of 8 output frames.
されたストリーク像あるいは，フレーミング像はCCDカ メラ入力型画像解析機で読み取る装置構成とした。

\section{3. 超音波の可視化一バルク波}

励起に用いたパルスレーザーの照射形状を整形するこ とで得られる超音波の平面波をプローブとし，探傷検査 を模擬した固体内の超音波伝播の可視化実験を行うこと で，単発パルスレーザー励起による超音波探傷の実現性 を探った。これまでも透明な固体内を伝播する超音波の 可視化は報告されている12,13)が，これらは1回の現象に対 して1枚の画像のみが取得されるが, 本方式は1回の現象 に対して一次元時間連続画像あるいは複数枚の2次元瞬間 像の撮影が可能なため, 超音波励起レーザーのパワー変 動の影響を除いた超音波伝播の観測が可能となり，また データ取得の時間を短縮することもできる．加えてレー ザーアブレーションのように塑性変形を伴うために現象 の再現が困難な超音波伝播の連続撮影も可能となる.

\section{1 実験方法}

超音波探傷試料の簡易モデルとして透明なアクリルブ ロックを用い，その端面にパルスYAGレーザーの2倍高調 波 (以後, YAG-SHGパルスレーザー) を照射し超音波を励 起した。このアクリルブロックを, Fig. 2に示すようなCW レーザー照明によるシャドウグラフ光学系 ${ }^{14)}$ の平行ビー ム内に配置し, 超音波の伝播による屈折率変化を可視化 した. YAG-SHGレーザーには，SPECTRON社製805G（パ

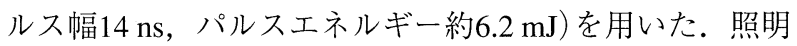
用のCWレーザーにはCrystal Laser 社製RLC-100-2449（ $\lambda=$ $640 \mathrm{~nm}, 20 \mathrm{~mW}$ 出力) を採用した。時間分解撮影はイメー ジコンバータ管を内蔵する高速度カメラ (浜松ホトニクス 製フレーミング・ストリークカメラC4187) を用いた。パ ルスレーザーとフレーミング・ストリークカメラのタイ ミング調整には，YAGレーザーコントローラのクロック 信号を基準として，ジーワン・ラボ社製タイミング回路 により同期を取った。

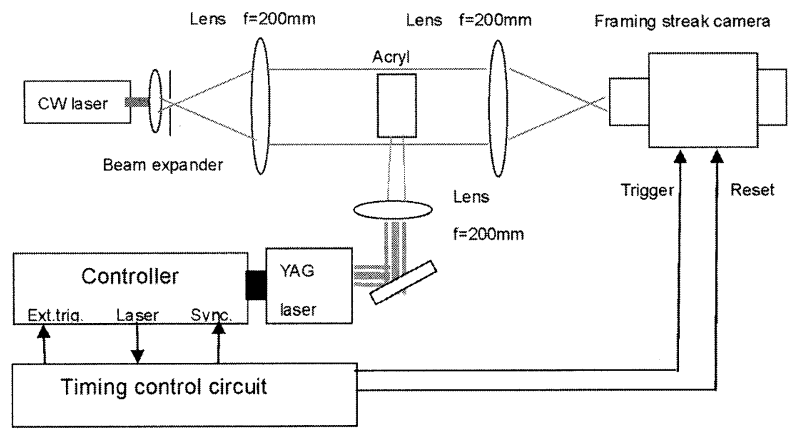

Fig. 2 Experimental configuration for shadow graph imaging with Spectron laser model $805 \mathrm{G}$ having a pulse energy of approx. $6.2 \mathrm{~mJ}$ and a pulse duration of approx. 14 ns. 


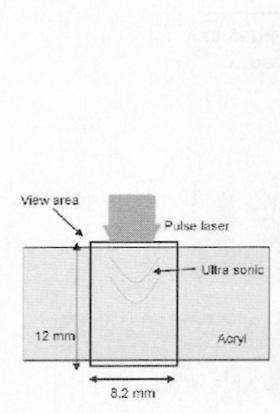

(a)

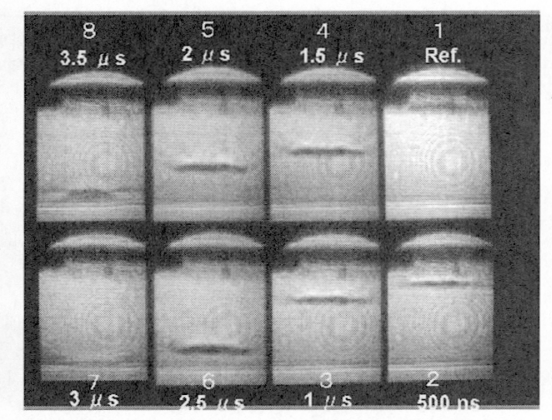

(b)
Fig. 3 (a) View area of acrylic block sample, and (b) framing images of ultrasonic plane waves.

\section{2 超音波探傷を模した波面の伝播}

光学系の調整により直径6 mmのYAG-SHGレーザーをア クリルブロックへ照射することで超音波の平面波を励起 し，この伝播をレーザーの照射タイミングを基準として 50 ナノ秒の露光時間, 500 ナノ秒のフレーム間隔でフレー ミング撮影した。 $10 \mathrm{~mm}$ 角で長さ100 mmのアクリルブ ロックにおける撮影視野の説明をFig. 3 (a)に示す。同図 (b)に示した超音波伝播画像おける黒い平面状の像は, 超 音波により生じた屈折率の高い部分に対応する. 発生し た平面波は，均一な材質においてはその波面が乱れるこ となく超音波が伝播していく様子が捉えられた.

次に超音波探傷試料の簡易モデルとして, 直径 $3 \mathrm{~mm} の$ 円筒状の穴を開けた同一形状のアクリルブロックを用い て，レーザー励起超音波の伝播・反射波形を撮影した。

Fig. 4 (a) は, 撮影視野の説明であり, 観測は穴の中心軸 方向からであることを示している，超音波は，穴に対し て上部から照射した。同図(b)は，このモデル試料におけ る超音波伝播の撮影像であり, 観測画像中央の輝度の高 い円形部分が穴である。

撮影像においては, アクリルブロック内部を伝播する 平面波(第1フレーム)が穴の部分で反射・回折し(第2，37 レーム), 反射波が試料表面に戻っていく(第4-6フレー ム)様子が捉えられた。 反射波が戻るタイミングは, 表面 から穴までの深さ情報を持ち, 反射波の3次元空間分布は 穴の形状情報を持つため, 反射超音波を時間的・空間的 に検出・解析することで検査試料の内部構造を推定でき る15)ことが分かる。

\section{4. 超音波の可視化一表面波}

非破壞計測は主に不透明素材を対象とするため, 検査 試料の表面に現れる反射超音波による表面弾性変位また は压力を2次元的に検出することで内部構造を推定する. 表面弾性変位を検出する方法は, 表面が鏡面の場合には 反射光を検出する方法が用いられるが，粗面の場合には Fabry-Perotポリマフィルム超音波センサを貼るなどの手 法16)やスペックル干渉計測法 ${ }^{17)}$ が報告されている。ま た，位相速度走査法18)を用いて励起した表面波による $\mathrm{Si}$ エハの表面欠陷評価法も提起されている。これらを模擬

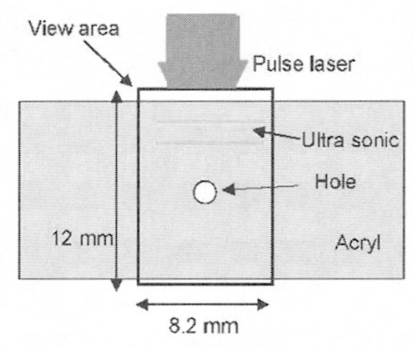

(a)

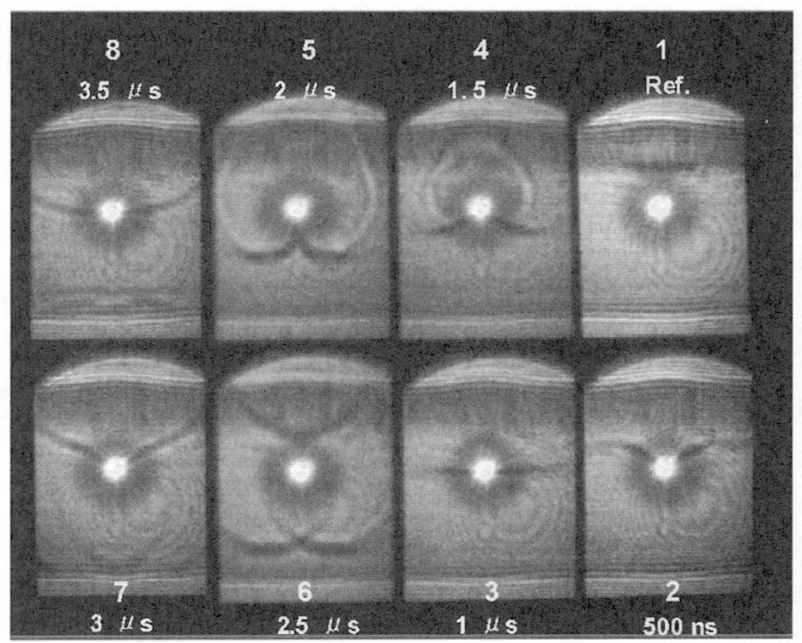

(b)

Fig. 4 (a) View area of acrylic block sample with a $3 \mathrm{~mm}$ dia. cylinder defect, and (b) framing images of propagating ultrasonic waves in the sample model.

し, 本稿では金属薄膜を伝播する超音波の検出 · 可視化 を試みた。

\section{1 実験方法}

超音波の音圧や変位は, 試料表面の反射光強度を変調 する19)。この特性を利用して, YAG-SHGパルスレーザー

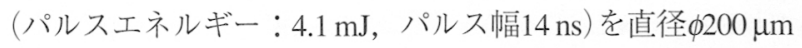
に集光・照射することによって金属薄膜(厚さ $2.75 \mathrm{~mm}$ $40 \mathrm{~mm}$ 角のアクリル基板の裏面に厚さ数 $10 \mathrm{~nm}$ のアルミニ ウムを蒸着)に励起した超音波の伝播をフレーミング撮影 およびストリーク撮影した。実験系はFig. 5に示すよう に, YAG-SHGパルスレーザーと照明用CWレーザー,

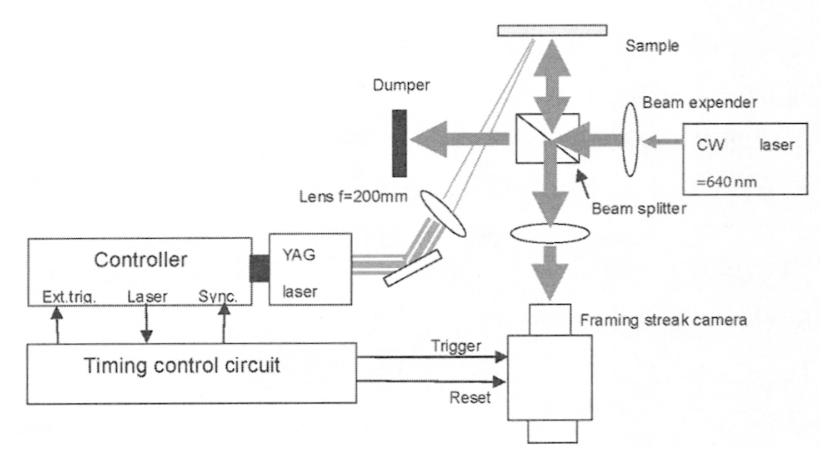

Fig. 5 Experimental configuration to observe dynamic reflection process of an $\mathrm{Al}$ mirror coated on an acrylic plate after YAG-SHG laser pulse exposure. 
ビームスプリッタ，フレーミング・ストリークカメラ C4187により構成した。CWレーザー光はビームスプリッ 夕で分岐され，金属薄膜プレートを垂直方向から落射照 明した。超音波で変調された反射光は再びビームスプ リッ夕を通過した後に金属表面像としてフレーミング . ストリークカメラ入力部に結像した．金属表面の動的挙 動はフレーミング・ストリークカメラで時間分解撮影さ れ, CCDカメラ入力型画像解析機により定量解析した.

\section{2 金属薄膜を伝わる表面波}

Fig. 6 (a)に示すように，YAG-SHGレーザーパルス照射 点を中心として, 幅 $9.3 \mathrm{~mm}$ で高さが14 mmの金属薄膜表面 をフレーミング撮影，及び幅 $12.3 \mathrm{~mm}$ で高さ $60 \mu \mathrm{m}$ の同一 表面をストリーク撮影にて時間分解観測した。パルス レーザーによって誘起された超音波が，金属薄膜をレー ザー照射点から同心円状に広がっていく様子が捉えられ た。同図(b) はパルスレーザー照射後 $3.5 \mu \mathrm{s}$ まで50 nsの露 光時間で， $500 \mathrm{~ns}$ 毎に得られたフレーミング像である。そ れぞれの夕イミングにおける超音波波面の広がりが捉え

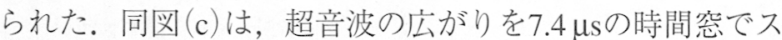
トリーク撮影した時間分解画像である。

時間分解画像Fig. 6 (b)，（c）の両者に伝播速度の異なる 2種類の波が観測された。ストリーク像Fig. 6 (c)における 波面の伝搬に伴う斜めの濃淡像の傾きを解析することで 第1波の伝播速度は約 $3.4 \mathrm{~km} / \mathrm{s}$ ，第2波の伝播速度は約 1.4 $\mathrm{km} / \mathrm{s}$ と解析された。また，レーザー照射位置に発生した振 動現象を解析するために, Fig. 6 (c)の中央に示した枠内 に置ける画像の輝度分布プロファイルを求めFig. 6 (d) に 示した。横軸は時間軸であり，縦軸は光強度を表す。時 間幅560 nsに相当するカーソル間に生じた4つの波の超音 波振動の周波数は7.2 MHzである。アルミニウムの横波音 速は $3.04 \mathrm{~km} / \mathrm{s}$ であることから，第1波はアルミ薄膜を伝わ るマッハ1.1で伝搬する衝撃波あるいは横波または板波と 考えられる、第2波はその発生メカニズムとしては，衝撃 波に伴って発生する渦輪のような現象，あるいはアルミ 薄膜内の励起電子によって発生するプラズマ状態の伝搬 による反射率の低い部分の伝搬と推定されるが，その詳 細なメカニズムの解明は, 今後の課題である。

一方，表面波発生と同時に生じた超音波バルク波のア クリル板反対端面からの反射は，レーザー照射時より 2.0 川後にアルミ薄膜に戻ると計算されるが，データには現れ ていない。この原因は, Fig. 6 (b)のフレーミング像の第 2駒から第4駒に現れているように，第1の超音波バルク波 が球面上に広がることでエネルギーが分散することに加 えて, CWレーザーの照明光強度不足により画像のS/Nが 十分でないためにその微弱な形状变化を捉えられなかっ たと考える。また，上記のように，観測された各種の反 射率の変調成分の発生メカニズムにも依存すると考えら れ，これらのメカニズムの探求は，今後はCWレーザー光 のパワーを上げるなどの対策を行ったうえで更なる議論 が必要である。

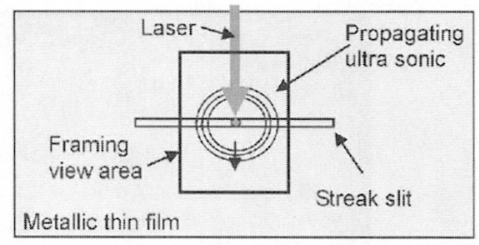

(a)

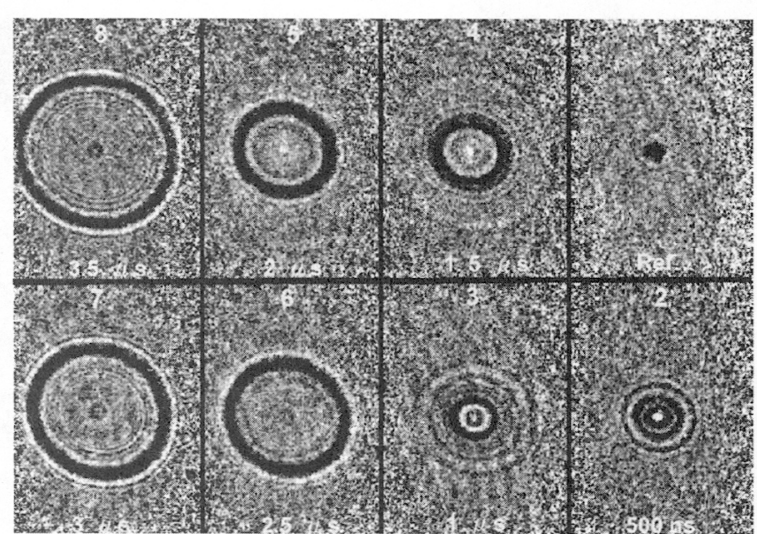

(b)

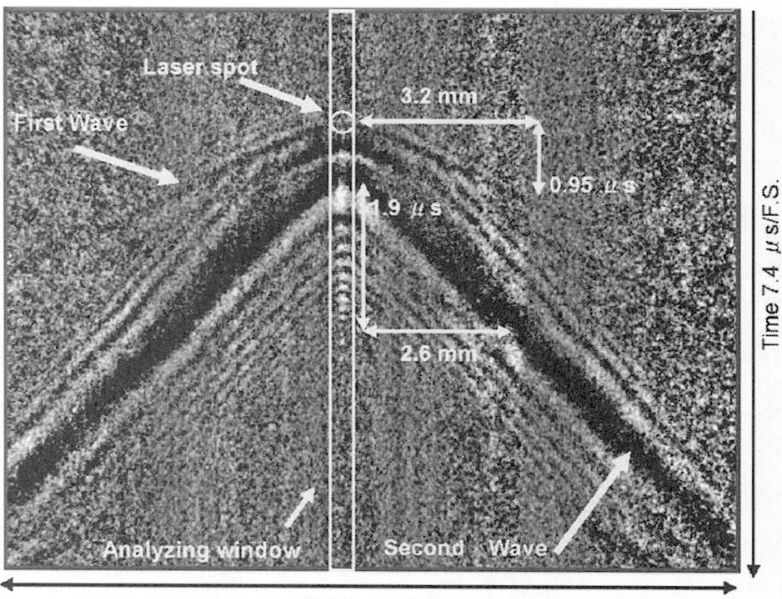

Space $12.3 \mathrm{~mm}$

(c)

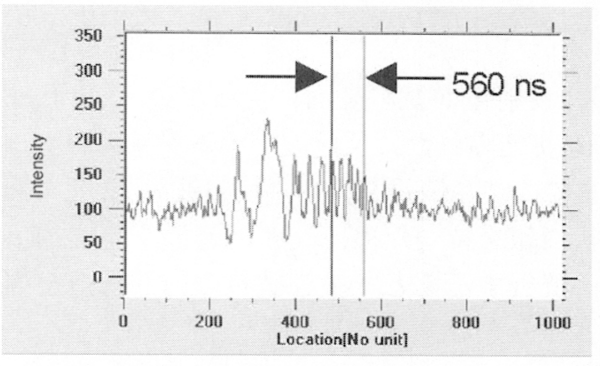

(d)

Fig. 6 (a) View area of Al mirror surface, (b) framing images, (c) streak image of propagating surface acoustic waves, and (d) indicates intensity profile of the streak image at the center of the YAG-SHG pulse excitation along time axis.

\section{5.まとめ}

超音波探傷計測を目指した超音波の可視化実験を通し て次の点が明らかとなった。

1) 本稿で提起した単発パルスレーザー励起超音波画像化 
装置は, 誘起された超音波の透明試料内部あるいは金 属蒸着表面に現れる超音波振動を高い時間分解能にて シングルイベント撮影することができる.

2) フレーミング計測法とストリーク計測法の双方を用い ることは，超音波の時間一多次元的な挙動を理解する ために極めて有効である。

3)2)により得られたデジタル化された撮影データから, 被測定試料内部や表面での超音波の時間 · 空間的振る 舞いを定量解析することができる.

4) 提起した単発パルスレーザー励起超音波画像化法の特 徴である単一イベントの超音波伝播を画像として捉え る手法は短時間に多くの情報を得るために有効であ り，分かりやすい検査法である。

一方，超音波探傷を行うために検査試料内部からの反 射超音波による表面弾性変位や反射率変化の定量化は必 要不可欠であり, 今回得られた種々の超音波などのダイ ナミックな挙動の詳細な発生メカニズムの解明，理論解 析とともに今後の課題である.

\section{謝 辞}

本研究は, 光産業創成大学院大学において浜松ホト二 クス(株)の支援をもとに行われたものです，本研究の機会 を与えて頂いた書馬 輝夫大学理事長兼浜松ホトニクス代 表取締役社長, 書馬 日出男取締役, 飯田 等システム事業 部長に深く感謝いたします。また光産業創成大学院大学 の山中正宣教授をはじめとした教員の皆様のご指導に感 謝いたします。最後に, 本研究は故土屋 裕教授のご指導 の下で始めたものです。改めて深く感謝いたします。

\section{参考文献}

1) O. Kotiaev，島田 義則：Laser Cross 211 (2005) 1 .

2) 田中崇雄：博士論文 (2002) p.44.

3）高坪 純治，今出 政明，茫 秋林，山本 茂之：日本機会学会論 文集 (C編) 65 (1999) p.61.

4）オリバライト，菅原美博，松田 理：応用物理 73 (2004) 732

5）高坪純治, 王 波, 津田 浩, 遠山暢之：日本機会学会論文 集 72 (2006) p.135.

6）竹下照雄：特願 2006-93797 (2006)

7) T. Takeshita, K. Suzuki, A. Takahashi, and M. Koishi: Proc. SPIE 1539 (1991) p. 2

8）竹下照雄, 鈴木一孝, 高橋 聡，小石 結 : ITEJ Technical Report 15 (1991) 31.

9）浜松ホトニクス(株)：光電子増倍管 (1993) p. 82.

10）土屋裕：超高速光エレクトロニクス，末田 止，神谷 武志 編 （倍風館, 1991）p.220.

11) 土屋 裕：博士論文 (1985) p.16.

12) M. Matsukura and Y. Ito: J. Physics: Conference Series 59 (2007) 749

13）三原穀, 大塚康典, 長 秀雄, 山中一司：第6回超音波によ る非破壊評価シンポジウム講演論文集 (1999) p.112.

14）流れの可視化学会：流れの可視化ハンドブック（朝倉書店, 1986) p. 310

15）椎名 穀：非侵襲・可視化技術ハンドブック，小川誠二上野 照剛 編 (NTS, 2007) p.153.

16) E. Z. Zang and P. Beard: Proc. SPIE 6086 (2006) 60860H-1.

17) 村田 滋, 駒井 優樹 : 日本機械学会論文集 200378 (2003) p.10.

18）長秀雄, 竹本幹男, 西野秀郎, 塚原祐輔, 佐藤倬暢, 佐藤治道, 中野禅, 山中一司：電子情報通信学会96 (1996) 41.

19) H. Maris: Scientific American (January, 1998) 86. 